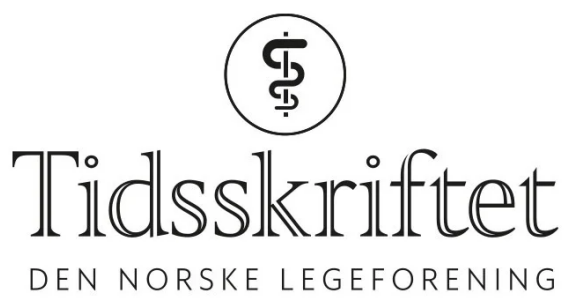

\title{
Fibrosen rundt implantater kan hemmes
}

FRA ANDRE TIDSSKRIFTER

HAAKON B. BENESTAD

Universitetet i Oslo

Aldrende bindevevsceller, såkalte senescentceller, kan fjernes medikamentelt og slik redusere fibrøs innkapsling av implantater. 


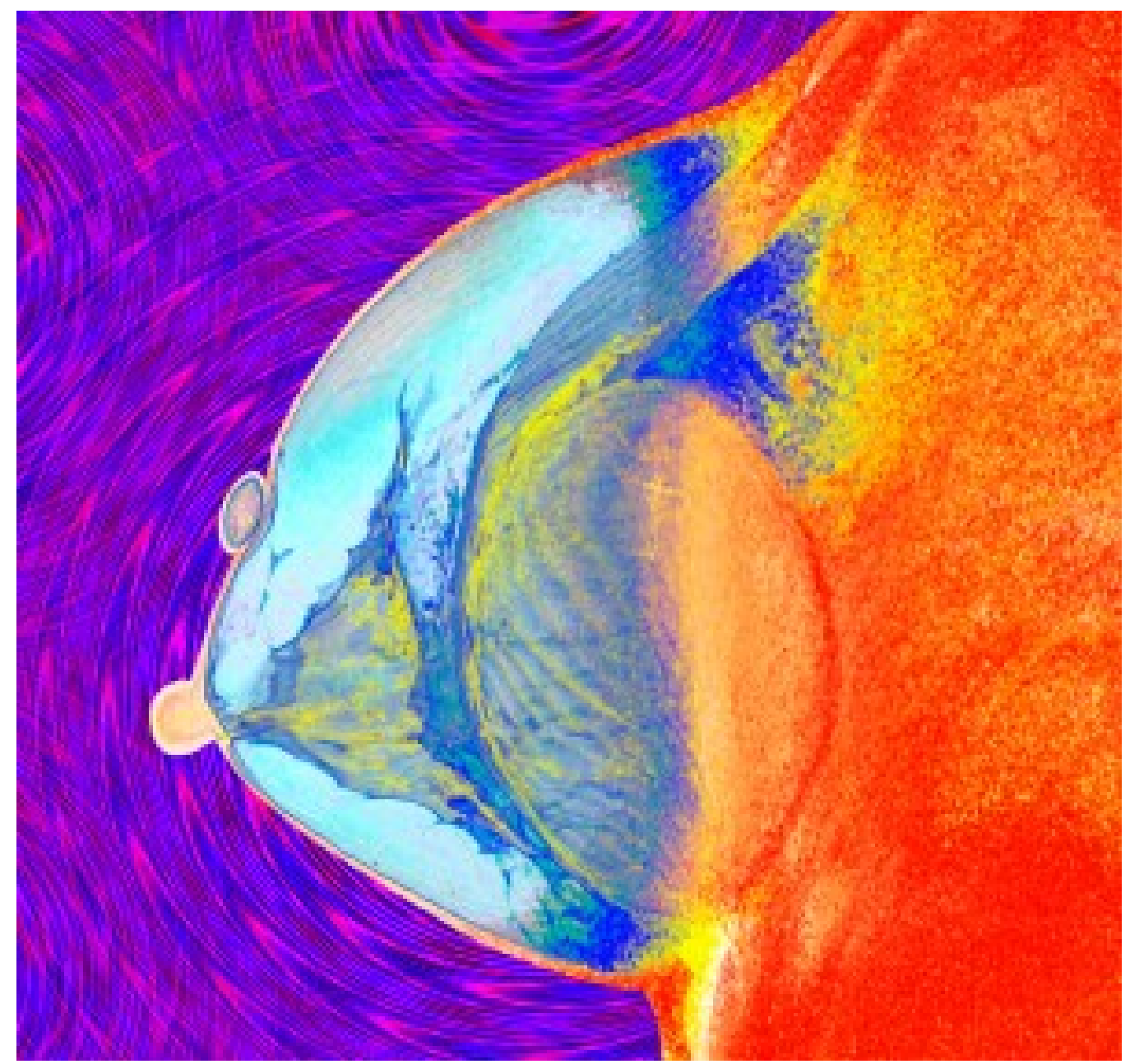

Illustrasjonsfoto: Science Photo Library / NTB Scanpix

Medisinske, syntetiske implantater, bl.a. brystimplantater, kan indusere inflammasjon og en vedvarende fremmedlegemerespons, slik at det dannes en fibrøs kapsel rundt implantatet. Denne kapseldannelsen kan svekke implantatets funksjon og være skadelig.

I en ny studie ble den fibrotiske reaksjonen studert ved å analysere sammensetningen av implantatkapslene rundt 12 fjernede brystimplantater (1). Av alle celletypene i en inflammasjonsreaksjon spilte interleukin 17-produserende CD4-hjelpelymfocytter, såkalte

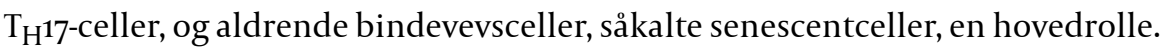

Videre studier i mus viste at anorganiske implantater fremkalte liknende produksjon av interleukin 17 (IL-17). Utskillelsen av interleukin 6 (som fremmer inflammasjon) fra senescentcellene var et tilstrekkelig signal for T-lymfocyttene til å produsere IL-17. IL-17defekte mus hadde både redusert fibroserespons på implantatene og færre aldrende fibroblaster i implantatkapselen.

- Dette er en fascinerende studie, sier Michael Daws, som er professor ved Institutt for medisinske basalfag, Universitetet i Oslo.

- Det forskes mye på senescentceller, hovedsakelig fordi man tror at det å fjerne dem kan forlenge livet. Men noen av disse cellene dannes ved vevsskade og bidrar til vevsreparasjon. Det er nok dette som skjer tidlig i responsen i denne studien, sier han.

- Interleukin 17 bidrar også til vevsreparasjon. Vanligvis ville disse cellene fjernes når vevet er ferdig reparert, men når implantatet fremdeles er der, vil nok lesjonen oppfattes som ikke reparert. Det oppstår da en mer kronisk situasjon med virksomme $\mathrm{T}_{\mathrm{H}^{17} \text {-celler og }}$ senescentceller, sier Daws.

- Ettersom interleukin 17 induserer senescentceller, mens interleukin 6 produsert av disse

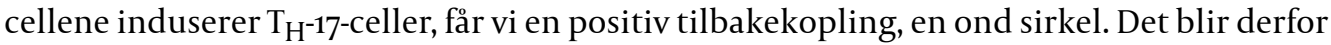
viktig å finne ut hvordan denne sirkelen kan stanses. Det gjenstår å se om legemidler mot 
senescentceller, som allerede er i klinisk bruk mot visse kreftformer, kan anvendes til å drepe senescentceller og redusere dannelsen av interleukin 17 og utvikling av implantatfibrose, sier Daws.

\section{LITTERATUR}

1. Chung L, Maestas DR, Lebid A et al. Interleukin 17 and senescent cells regulate the foreign body response to synthetic material implants in mice and humans. Sci Transl Med 2020; 12: eaax3799. [PubMed][CrossRef]

Publisert: 7. september 2020. Tidsskr Nor Legeforen. DOI: 10.4045/tidsskr.20.0504

(C) Tidsskrift for Den norske legeforening 2023. Lastet ned fra tidsskriftet.no 26. april 2023. 